\title{
EFFECT OF PARTICLES SIZE ON THE MECHANICAL PROPERTIES OF SiC-REINFORCED ALUMINIUM 8011 COMPOSITES
}

\section{VPLIV VELIKOSTI DELCEV NA MEHANSKE LASTNOSTI S SiC OJAČANIH ALUMINIJEVIH 8011 KOMPOZITOV}

\author{
Nagaraj Ashok, Palanisamy Shanmughasundaram \\ Karpagam Academy of Higher Education, Karpagam University, Department of Mechanical Engineering, Coimbatore 641021, India \\ sunramlec@rediffmail.com, ashok2488@rediffmail.com \\ Prejem rokopisa - received: 2016-08-11; sprejem za objavo - accepted for publication: 2016-11-14
}

doi:10.17222/mit.2016.252

\begin{abstract}
The effects of the $\mathrm{SiC}$ particle size on the mechanical properties of aluminium 8011 -SiC composites are reported. Three different particle sizes of $\operatorname{SiC}(63,76,89) \mu \mathrm{m}$ with two different mass fractions of $2 \%$ and $4 \%$ reinforced with aluminium 8011 were processed using the stir-casting method. The mechanical properties, like hardness, tensile strength, yield strength, ductility, and toughness, of the composites and the unreinforced alloy were tested. It was observed that the hardness, tensile strength, yield strength, ductility, and toughness increase with a decrease in the particle size of the SiC. The increase in weight fraction of the $\mathrm{SiC}$ improves all the mechanical properties, except for the ductility and toughness of the composites. The results reveal that the fine $63 \mu \mathrm{m}$ (220 mesh) $\mathrm{SiC}$ particles introduced superior mechanical properties compared to the intermediate $76 \mu \mathrm{m}$ (180 mesh) SiC particles and the coarse $89 \mu$ m (150 mesh) SiC.

Keywords: composites, particle size, stir casting method, weight fractions, mechanical properties

Delo poroča o učinkih velikosti delcev $\mathrm{SiC}$ na mehanske lastnosti aluminijevih 8011 kompozitov. Tri različne velikosti delcev $\operatorname{SiC}(63,76,89) \mu \mathrm{m} z$ dvema različnima deležema teže $(2$ in 4$) \%$, ojačane $\mathrm{z}$ aluminijem 8011 , so bile obdelane $\mathrm{z}$ metodo mešanja in litja. Testirane so bile mehanske lastnosti, kot so: trdota, natezna trdnost, meja tečenja, duktilnost in žilavost kompozitov in neojačane zlitine. Ugotovljeno je bilo, da se trdota, natezna trdnost, meja tečenja, duktilnost in žilavost povečajo z zmanjšanjem velikosti delcev SiC. Povečanje deleža masnega odstotka SiC izboljšuje vse mehanske lastnosti razen razteznosti in žilavosti kompozitov. Rezultati kažejo, da drobni $63 \mu \mathrm{m}$ (220 mesh) SiC delci pokažejo nadpovprečne mehanske lastnosti v primerjavi z vmesnim $76 \mu \mathrm{m}$ (180 mesh) SiC delci in grobimi $89 \mu \mathrm{m}$ (150 mesh) SiC.

Ključne besede: kompoziti, velikost delcev, metoda mešanja in litja, masni deleži, mehanske lastnosti
\end{abstract}

\section{INTRODUCTION}

Aluminium metal-matrix composites are being used as materials for automobile and aerospace applications. Aluminium- and magnesium-based Metal-Matrix Composites (MMCs) are an important class of high-potential engineering materials. ${ }^{1}$ Aluminium alloy reinforced with silicon carbide displays better mechanical and tribological properties than the unreinforced alloy because of their high strength-to-weight ratio. Silicon carbide is often the preferred reinforcement in the production of aluminium powder composites. ${ }^{2}$ Stir casting can be used to fabricate the composites for a better homogenous distribution of reinforcement particles in the matrix. P. Shanmughasundaram et al. ${ }^{3}$ investigated the effect of the addition of fly ash on the mechanical and wear behaviour of Aluminium-fly ash composites. The composites were prepared with the varying weight percentage of fly ash $(5,10,15,20$ and 25) by a two-step stircasting method. They concluded that hardness, tensile strength and compressive strength of the composites increases up to the addition of $15 \%$ of mass fractions of fly ash, so it is the maximum reinforcement level to obtain the desired property. S. G. Kulkarni et al. ${ }^{4}$ inves- tigated the effect of fly ash and alumina on the mechanical property of aluminium 356 alloy. They have concluded that the addition of fly ash and alumina increases the mechanical properties like hardness, tensile strength and compressive strength of the composites. Sudarshan et al. ${ }^{5}$ analysed the mechanical properties of Al356-fly ash composites prepared by stir casting and hot extrusion. They used narrow-size-range (53-106 $\mu \mathrm{m})$ and wide-size-range $(0.5-400 \mu \mathrm{m})$ fly ash particles as reinforcement. Their results revealed that small size particles (53-106 $\mu \mathrm{m})$ display higher mechanical properties than the larger size particles. P. Shanmughasundaram et al. ${ }^{6}$ applied ANOVA and Taguchi methods for the selection of optimum level of parameters to obtain the maximum mechanical properties of Al-fly ash composites. They concluded that a modified two-step stir-casting method enhances the uniform distribution of fly ash particles in the aluminium matrix and improves the mechanical properties. Baradeswaran et al. ${ }^{7}$ investigated the mechanical and wear properties of $\mathrm{Al}$ $7075 / \mathrm{Al}_{2} \mathrm{O}_{3} /$ graphite hybrid composites. The hybrid composites were prepared with the reinforcement of different weight percentages of alumina $(2,4,6$, and 8$)$ 
and $5 \%$ mass fractions of graphite. They concluded that the mechanical properties increased due to the increase in solid-solution strengthening. V. Ramnath et al. ${ }^{8}$ analysed the mechanical behaviour of aluminium-boron carbide-alumina composites produced by the stir-casting method. They concluded that the hardness and toughness of the aluminium-boron carbide ( $3 \%$ of mass fractions) alumina (2\% of mass fractions) composites exhibit superior properties than the other composites and unreinforced alloy. Veereshkumar et al. ${ }^{9}$ have studied Al6061-SiC and $\mathrm{Al} 7075-\mathrm{Al}_{2} \mathrm{O}_{3}$ composites produced by liquid metallurgy technique. R. Harichandran et al. ${ }^{10}$ investigated the effect of micro and nanoparticle reinforcement of boron carbide on the aluminium alloy by ultrasonic cavitation-assisted stir casting. T. Thirumalai et al. ${ }^{11}$ analysed the aluminium matrix composites reinforced with boron carbide and graphite fabricated by the stir-casting method. Different weight fractions of boron carbide $(3,6,9$, and $12 \%$ of mass fractions) and graphite ( $3 \%$ of mass fractions) were reinforced with LM25Al alloy. Their results revealed that the hardness of the composites was higher than that of the unreinforced alloy. J. Hashim et al. ${ }^{12}$ analysed the low-cost stir-casting method for the preparation of high-quality aluminium-SiC composites. They found that by controlling the various process parameters like position of the impeller, size of the impeller, holding temperature, stirring speed and addition of weight percentage of reinforcement a wide range of mechanical properties were obtained. P. Pugalenthi et al. ${ }^{13}$ conducted tests on the mechanical properties of 7075 aluminium alloy reinforced with $2 \%$ of mass fractions of $\mathrm{SiC}$ and $(3,5,7,9) \%$ of mass fractions of alumina hybrid composites. Their result revealed that the hardness and tensile strength of the composites increase with an increase in the reinforcement of $\mathrm{SiC}$ and alumina. S. M. L. Nai et al. ${ }^{14}$ analysed the effect of stirring speed on the synthesis of $\mathrm{Al} / \mathrm{SiC}$ based functionally gradient materials. They concluded that an increase of the stirring speed will lead to a more homogeneous distribution of $\mathrm{SiC}$ particulates alongside the deposition direction. N. Radhika et al. ${ }^{15}$ analysed the mechanical properties and tribological behaviour of $\mathrm{LM} 25 / \mathrm{SiC} / \mathrm{Al}_{2} \mathrm{O}_{3}$ composites with reinforcement of $(5,10,15) \%$ mass fractions of $\mathrm{SiC}$ and $(5$, $10,15) \%$ of mass fractions of alumina. It was found that the composites with reinforcement of $30 \%(15 \% \mathrm{SiC}$ and $15 \%$ alumina) have higher hardness and tensile strength than the unreinforced base alloy. K. Komai et al. ${ }^{16}$ investigated the tensile and fatigue fracture behaviour of $\mathrm{A} 17075 / \mathrm{SiC}$ composites. They reported that the mechanical properties of $\mathrm{Al} 7075 / \mathrm{SiC}$ composites were superior to the unreinforced alloy. T. J. A. Doel et al. ${ }^{17}$ analysed the tensile properties of $\mathrm{Al}-\mathrm{SiC}$ composites. The three different particle size of $\operatorname{SiC}(5,13,60) \mu \mathrm{m}$, were used as reinforcement. They concluded that coarse $\mathrm{SiC}$ particles fracture easily at low load than the fine and intermediate $\mathrm{SiC}$ particles. C. Sun et al. ${ }^{18}$ investigated the effect of SiC particle size on the mechanical properties of aluminium-SiC composites. They concluded that the tensile strength and yield strength of the composites increases due to the addition of fine $\mathrm{SiC}$ particles. H. C. Anilkumar et al. ${ }^{19}$ investigated the effect of fly ash particle size (4-25, 45-50 and 75-100) $\mu \mathrm{m}$ and reinforcement weight fractions $(10,15$ and 20$) \%$ on the mechanical properties of Al6061 composites reinforced with fly ash. Their result reveals that the tensile strength, compressive strength and hardness of the aluminium alloy (Al 6061) composites increased with an increase in the weight fraction of reinforced fly ash and decreased with an increase in the particle size of the fly ash. M. $\mathrm{Kok}^{20}$ analysed the effect of particle size and the weight fraction of alumina on the mechanical properties of A12024-alumina composites. Three different particle sizes (16, 32 and 66) $\mu \mathrm{m}$ and three different mass fractions (10, 20 and 30) \% of alumina were used as the reinforcement to produce composites by the vortex method, followed by applied pressure. The results reveal that the reinforcement of fine alumina particles exhibits a higher mechanical property than the intermediate and coarse particles. M. Rahimian et al. ${ }^{21}$ investigated the effect of particle size and weight fraction of alumina on the mechanical properties of aluminium matrix composite produced by powder metallurgy. Three different weight fractions $(5,10,15)$ and three different particle sizes of alumina $(3,12,48) \mu \mathrm{m}$ were used as the reinforcement. Their results show that the finer particle ( $3 \mu \mathrm{m})$ has the highest yield strength, hardness, compressive strength, elongation than the intermediate $(12 \mu \mathrm{m})$ and coarse particle $(48 \mu \mathrm{m})$ reinforcement. $\mathrm{M}$. Kok et al. ${ }^{22}$ examined the effect of two different particle sizes of alumina on the mechanical and wear behaviour of the Al 2024 alloy. They revealed that the hardness and tensile strength of the smaller particle reinforcement were much higher than the larger particle size. S. Mahdavi et al..$^{23}$ analysed the hardness and wear behaviour of Al6061 composites with the reinforcement of three different SiC particles $(19,93,146) \mu \mathrm{m}$. Their result shows that the hardness increases with a decrease in the particle size of the $\mathrm{SiC}$ reinforcement. From the literature it was observed that the mechanical properties of the composites depend on the size and quantity of the reinforcement particles. Earlier studies indicated that the mechanical properties of the composites can be improved with a decrease in the particle size and an increase in the reinforcement content. Hence, a systematic study has to be carried out to study the effect of particle size and weight fraction of reinforcement on the mechanical behaviour of the composites. In this present work A18011-SiC composites with the reinforcement of three different particle sizes of $\operatorname{SiC}(63,76$ and 89) $\mu \mathrm{m}$ and two different weight fractions (2 and 6) \% of $\mathrm{SiC}$ were fabricated using the stir-casting method and its various mechanical properties like hardness, tensile 
strength, yield strength, ductility and toughness were tested.

\section{EXPERIMENTAL PART}

\subsection{Stir-casting method}

In this research work, $\mathrm{Al} 8011-\mathrm{SiC}$ composites were fabricated with three different particle sizes $89 \mu \mathrm{m}$ (coarse), $76 \mu \mathrm{m}$ (intermediate) and $63 \mu \mathrm{m}$ (fine) and two different weight fractions ( 2 and 6$) \%$ of $\mathrm{SiC}$ were used as reinforcement by stir the casting method. The composition of Al 8011 alloy is presented in Table 1.

Table 1: Composition of Al alloy 8011 alloy

\begin{tabular}{|c|c|}
\hline Element & $\begin{array}{c}\text { In mass frac- } \\
\text { tions, }(w / \%)\end{array}$ \\
\hline $\mathrm{Al}$ & 97.14 \\
\hline $\mathrm{Si}$ & 0.53 \\
\hline $\mathrm{Fe}$ & 0.99 \\
\hline $\mathrm{Cu}$ & 0.27 \\
\hline $\mathrm{Mn}$ & 0.21 \\
\hline $\mathrm{Mg}$ & 0.25 \\
\hline $\mathrm{Cr}$ & 0.049 \\
\hline $\mathrm{Zn}$ & 0.19 \\
\hline $\mathrm{Ti}$ & 0.028 \\
\hline $\mathrm{Pb}$ & 0.10 \\
\hline $\mathrm{Ca}$ & 0.008 \\
\hline $\mathrm{Ni}$ & 0.045 \\
\hline
\end{tabular}

Stir-casting setup that was used to fabricate the composites is shown in Figure 1.

To remove the moisture content from the SiC particles, they were preheated for $60 \mathrm{~min}$ in a separate muffle furnace. Aluminium 8011 was added to the graphite crucible and the furnace temperature was maintained at

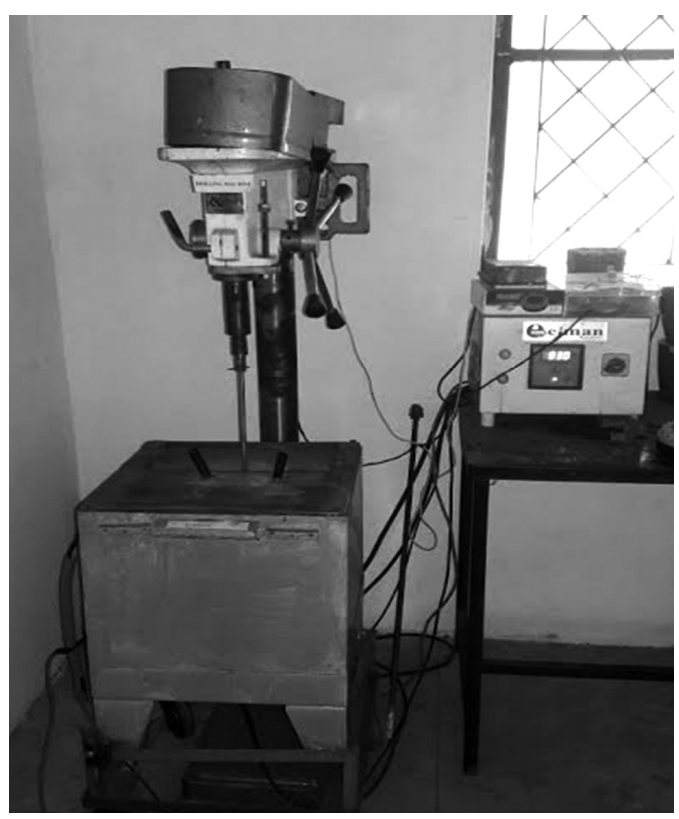

Figure 1: Stir casting setup ${ }^{3}$

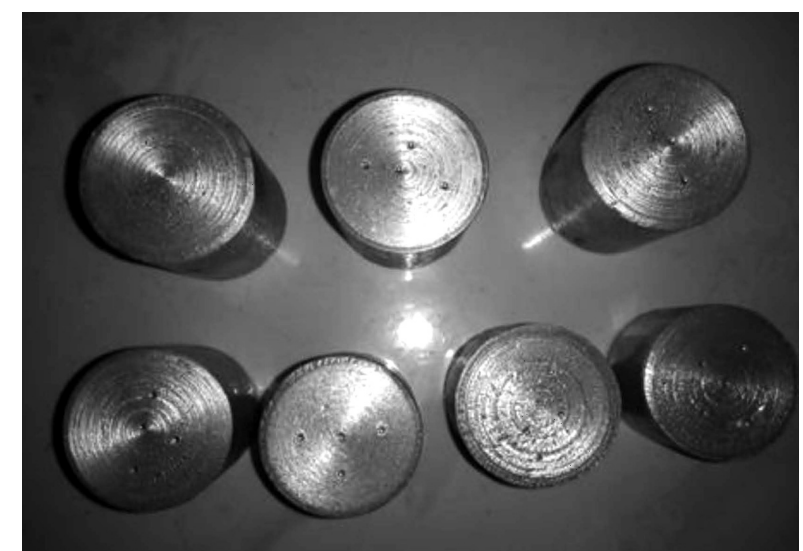

Figure 2: Examined hardness test samples of Al8011 and Al 8011-SiC composites

$780{ }^{\circ} \mathrm{C}$, then the $\mathrm{Al}$ scraps were melted completely. The melt temperature was reduced to $720{ }^{\circ} \mathrm{C}$ to obtain the semi-solid state, then the preheated $\mathrm{SiC}$ particles and $1.5 \%$ of mass fractions of $\mathrm{Mg}$ was added to the molten slurry. Stirring was done for $5 \mathrm{~min}$. $\mathrm{Mg}$ were added to the mixture to increase the wettability between the $\mathrm{Al}$ matrix and SiC particles. The stirring speed was maintained at $300 \mathrm{~min}^{-1}$ throughout the process. Then, finally again the temperature was raised to the liquid state and poured into the mould for solidification.

\section{MECHANICAL PROPERTIES}

\subsection{Hardness test}

The hardness tests of Al8011-SiC composites and unreinforced alloy were carried out using Rockwell hardness machine MSM model with ASTM E18:2014 standard with 1/16" inch ball indenter with a load of $980 \mathrm{~N}$. The loading time for the test period was $15 \mathrm{~s}$. The average of three readings was taken to eliminate the error at room temperature. The examined hardness test samples of Al8011 and Al 8011-SiC composites are shown in Figure 2.

\subsection{Tensile test}

Tensile tests were carried out using UTM testing machine M30 model as per ASTM E8:2015 standard for the Al8011 and Al8011-SiC composites. Three samples were taken and tested and the average of three test readings was taken and noted. The examined tensile test samples of Al8011 and Al 8011-SiC composites are shown in Figure 3.

\subsection{Impact test}

The toughness test was carried out by using charpy impact test machine (AIT-300-EN). The energy required to break the specimen was measured in terms of Joules. The final energy measured was the difference between the total energy supplied to break the specimen to the en- 
N. ASHOK, P. SHANMUGHASUNDARAM: EFFECT OF PARTICLES SIZE ON THE MECHANICAL PROPERTIES ...

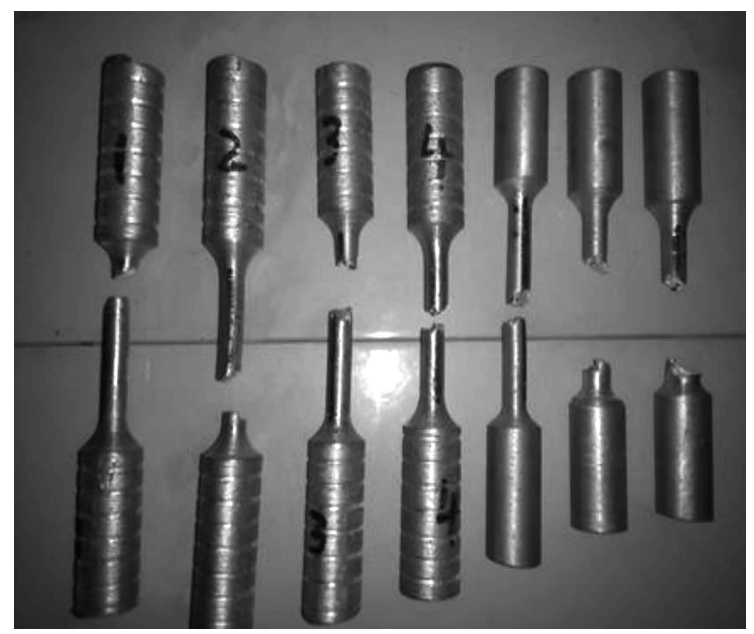

Figure 3: Examined tensile test samples of Al8011 and Al 8011-SiC composites

ergy available after the specimen fracture. The test method used was ISO-148-1:2009. The standard specimen size for this impact test method was $10 \mathrm{~mm} \times 10$ $\mathrm{mm} \times 55 \mathrm{~mm}$. Three specimens were tested and the average of three readings was noted. Examined Charpy impact test samples of Al8011 and $\mathrm{Al} 8011-\mathrm{SiC}$ composites are shown in Figure 4.

Mechanical properties of pure Al and A18011-SiC Composites are presented in Table 2.

Table 2: Mechanical Properties of A18011-SiC Composites

\begin{tabular}{|c|c|c|c|c|c|}
\hline $\begin{array}{c}\text { Sic } \\
(w / \%)\end{array}$ & $\begin{array}{c}\text { Hardness } \\
(\mathrm{RHB})\end{array}$ & $\begin{array}{c}\text { Yield } \\
\text { strength } \\
(\mathrm{MPa}\end{array}$ & $\begin{array}{c}\text { Tensile } \\
\text { strength } \\
(\mathrm{MPa})\end{array}$ & $\begin{array}{c}\text { Elonga- } \\
\text { tion \% }\end{array}$ & $\begin{array}{c}\text { Tough- } \\
\text { ness (J) }\end{array}$ \\
\hline 0 & 90 & 46 & 67 & 7 & 10 \\
\hline $\begin{array}{c}2 \% \\
(89 \mu \mathrm{m})\end{array}$ & 92 & 54 & 73 & 7.5 & 15 \\
\hline $\begin{array}{c}2 \% \\
(76 \mu \mathrm{m})\end{array}$ & 94 & 58 & 78 & 7.8 & 16 \\
\hline $\begin{array}{c}2 \% \\
(63 \mu \mathrm{m})\end{array}$ & 96 & 63 & 84 & 8.4 & 17 \\
\hline $\begin{array}{c}6 \% \\
(89 \mu \mathrm{m})\end{array}$ & 98 & 76 & 98 & 7.2 & 12 \\
\hline
\end{tabular}

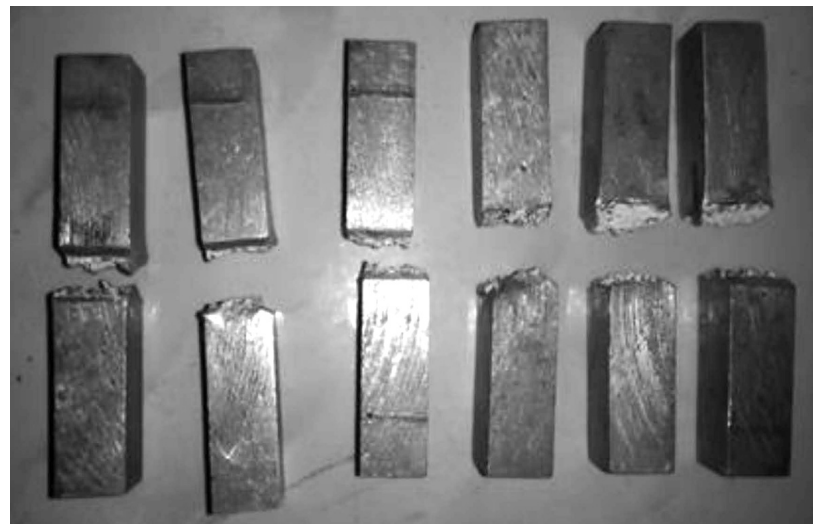

Figure 4: Examined Charpy impact test samples of Al8011 and Al 8011-SiC composites

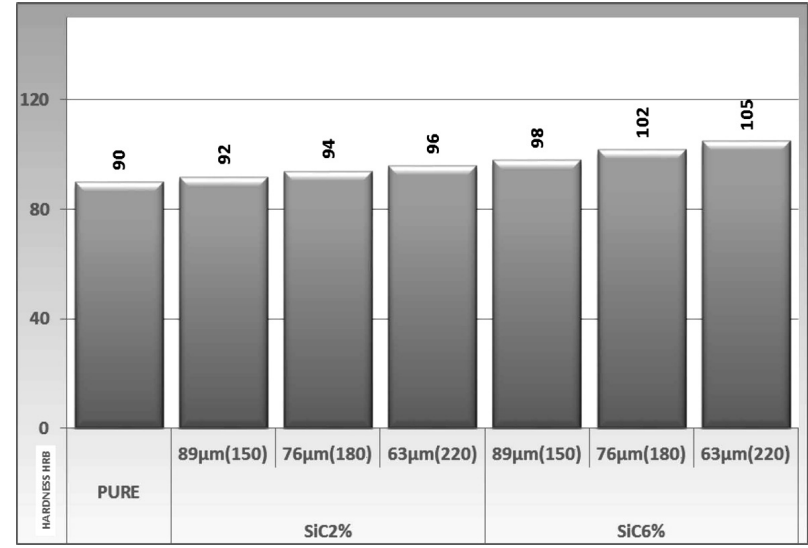

Figure 5: Effect of mesh size of $\mathrm{SiC}$ on the hardness of Al8011-SiC composites

\begin{tabular}{|c|c|c|c|c|c|}
\hline $\begin{array}{c}6 \% \\
(76 \mu \mathrm{m})\end{array}$ & 102 & 81 & 105 & 7.4 & 13 \\
\hline $\begin{array}{c}6 \% \\
(63 \mu \mathrm{m})\end{array}$ & 105 & 87 & 111 & 7.7 & 14 \\
\hline
\end{tabular}

\section{RESULTS AND DISCUSSION}

From Figure 5 it can be observed that as the particle size decreases the hardness of the composite increases for $2 \%$ and $6 \%$ of mass fractions reinforcement of $\mathrm{SiC}$. The hardness of Al8011-SiC-63 $\mu$ m (220 mesh) for $6 \%$ of mass fraction was observed to be $105 \mathrm{HRB}$, which was $16 \%$ more than the unreinforced alloy (90 HRB). Hard SiC particles act as a barrier to the applied load. Hardness of the Al8011-SiC composites was greater than the unreinforced alloy because of the hard nature of the $\mathrm{SiC}$ particles. The addition of hard ceramic particles increased the bulk hardness of the aluminium alloy. Fine particle size $63 \mu \mathrm{m}$ (220 mesh) reinforcement of SiC exhibit superior hardness than the intermediate SiC-76 $\mu \mathrm{m}$ (180 mesh) and coarse SiC-89 $\mu \mathrm{m}$ (150 mesh). This result was similar to the statement concluded by M. Kok. ${ }^{20}$ M. Kok reported that the hardness of the composites increased with decreasing size and increasing weight fraction of the reinforcement particles. The increase in hardness was due to the presence of a larger interfacial area

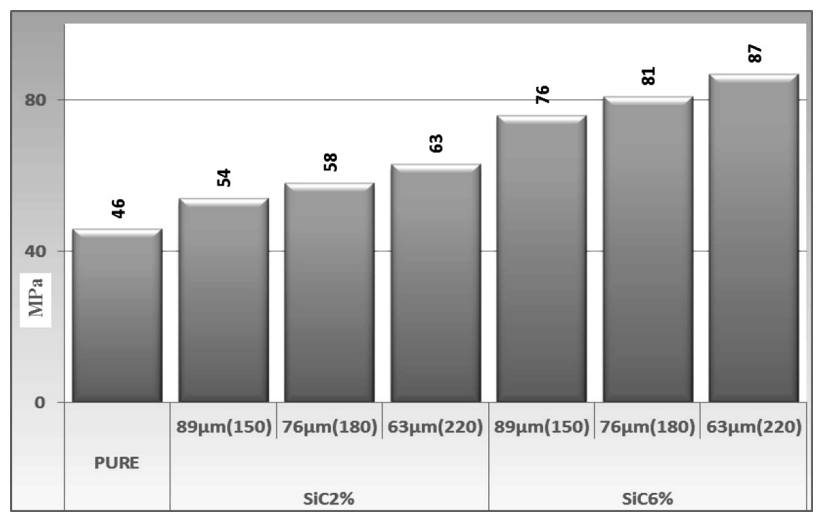

Figure 6: Effect of mesh size of $\mathrm{SiC}$ on the yield strength of Al8011-SiC composites 


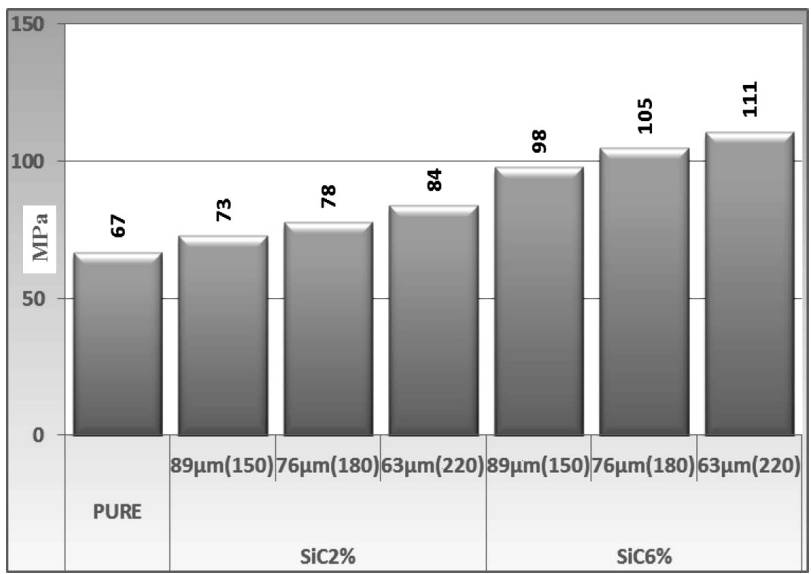

Figure 7: Effect of mesh size of $\mathrm{SiC}$ on the tensile strength of A18011-SiC composites

between the soft and hard phases. Decreasing the alumina particle size increases the hardness. A similar observation was made by M. Rahimian. ${ }^{21}$

From Figure 6 it is observed that yield strength increases as the weight fraction of $\mathrm{SiC}$ increases. The yield strength of Al8011-6\% of mass fractions of SiC-63 $\mu \mathrm{m}$ (220 mesh) was observed to be $87 \mathrm{MPa}$ which was $89 \%$ higher than the unreinforced alloy. The yield strength also increases with the decrease in particle size of $\mathrm{SiC}$. It was noted that the value of yield strength was $54 \mathrm{MPa}$ for Al8011-2 \% of mass fractions of SiC-89 $\mu \mathrm{m}(150$ mesh), $58 \mathrm{MPa}$ for Al8011-2\% of mass fractions of $\mathrm{SiC}-76 \mu \mathrm{m}$ (180 mesh) and $63 \mathrm{MPa}$ for Al8011-2 \% of mass fractions of SiC-63 $\mu \mathrm{m}$ (220 mesh), that was $16 \%$ increase when compared to the 150 mesh size.

From Figure 7 it is clear that the tensile strength of the composites was higher than the pure Aluminium 8011. The tensile strength of unreinforced Al8011 was $67 \mathrm{MPa}$ and the value increased to $84 \mathrm{MPa}$ for A18011-2\% of mass fractions of SiC-63 $\mu \mathrm{m}$ (220 mesh). An increase of $25 \%$ in tensile strength was observed. Similarly 111 MPa for Al 8011-6\% of mass fractions of SiC-63 $\mu \mathrm{m}$

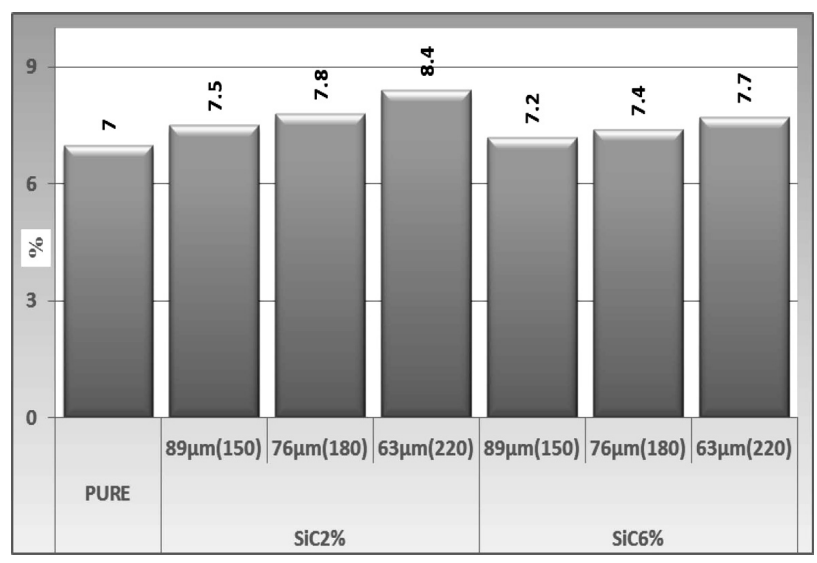

Figure 8: Effect of mesh size of $\mathrm{SiC}$ on the elongation of Al8011-SiC composites

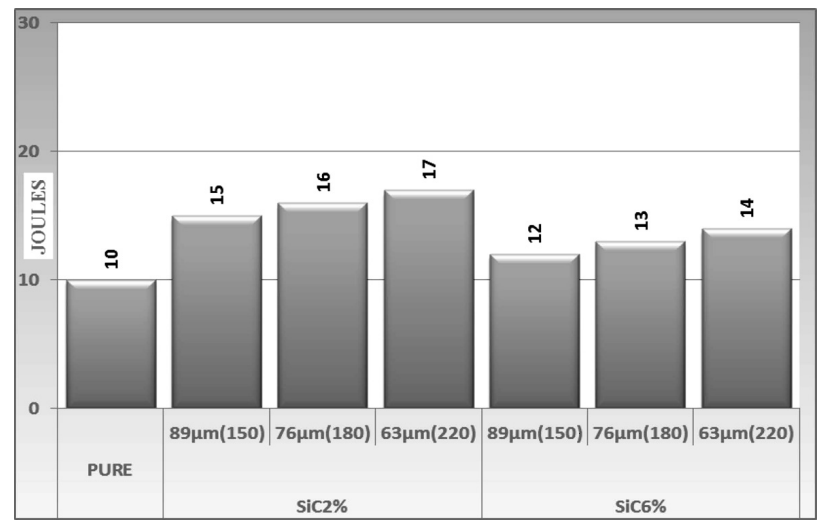

Figure 9: Effect of mesh size of SiC on the toughness of A18011-SiC composites

(220 mesh), increase of $65 \%$ was observed when compared to the unreinforced alloy.

From Figure 8 it is clear that the elongation of the composites increases with the decrease in the particle size. The elongation tends to decrease when the amount of reinforcement increases. The Al 8011-2 \% of mass fractions of $\mathrm{SiC}$ has a higher elongation than the A18011-6\% of mass fractions of $\mathrm{SiC}$ composites. The elongation decreases to $7.7 \%$ from $8.4 \%$ drop of $9 \%$ was observed. The increase in tensile strength and yield strength was due to the increase in dislocation density caused by the reinforcement of the hard $\mathrm{SiC}$ particles. As smaller reinforcement particle size reduces the distance between the reinforcement particles, the movement of dislocations tends to decrease, leading to a higher strength of the composites. The grain boundary acts as a barrier to the movement of dislocations caused by the plastic deformation. Therefore, at a higher mess size, high grain boundaries are formed, which act as a barrier against the movement of the dislocation.

From Figure 9 it is observed that the highest toughness of $17 \mathrm{~J}$ was observed for Al8011-2 \% SiC-63 $\mu \mathrm{m}$ (220 mesh). The value was $16 \mathrm{~J}$ for Al8011-2\% of mass fractions of $\mathrm{SiC}-76 \mu \mathrm{m}(180 \mathrm{mesh})$ and $15 \mathrm{~J}$ for Al8011-2 \% of mass fractions of SiC-89 $\mu$ m (150 mesh). But the toughness decreases for the reinforcement of $6 \%$ of mass fractions of $\mathrm{SiC}$ particles.

\section{CONCLUSIONS}

Al 8011-SiC composites were produced successfully by the stir-casting method and a homogenous distribution of $\mathrm{SiC}$ particles in the Al8011 matrix was obtained. From the tests conducted the following conclusions can be drawn:

1. Hardness increased with the decrease in SiC particle size. The highest hardness (105 HRB) was obtained for $6 \%$ of mass fractions of $\mathrm{SiC}$ particle reinforced composites with $63 \mu \mathrm{m}$ particle size.

2. The coarse particle size of $\mathrm{SiC}$ has a lesser yield strength and tensile strength. The highest amount of 


\section{MATERIALI IN TEHNOLOGIJE/MATERIALS AND TECHNOLOGY (1967-2017) - 50 LET/50 YEARS}

\section{N. ASHOK, P. SHANMUGHASUNDARAM: EFFECT OF PARTICLES SIZE ON THE MECHANICAL PROPERTIES ...}

yield strength and tensile strength were $87 \mathrm{MPa}, 111$ MPa for the sample containing $6 \%$ of mass fractions of $\mathrm{SiC}$ with $63 \mu \mathrm{m}$ particle size.

3. Elongation decreased as the weight fraction of $\mathrm{SiC}$ increases. The $6 \%$ of mass fractions of $\mathrm{SiC}$ particle reinforced composite with $63 \mu \mathrm{m} \mathrm{SiC} \mathrm{particles} \mathrm{has}$ the elongation of $7.7 \%$ which was $8 \%$ less than the $2 \%$ of mass fractions of $\mathrm{SiC}$ particle-63 $\mu \mathrm{m}(220$ mesh).

4. Toughness increased with the decrease in particle size for both the $2 \%$ and $6 \%$ mass fractions of $\mathrm{SiC}$ particle reinforced composites. The highest amount of toughness was $17 \mathrm{~J}$ for the sample containing $2 \%$ of mass fractions of $\mathrm{SiC}$ with $63 \mu \mathrm{m} \mathrm{SiC}$ particles.

Hardness, yield strength, and tensile strength increase with the increase in weight fraction of $\mathrm{SiC}$, while the toughness and ductility decrease. Fine reinforcement of SiC-63 $\mu \mathrm{m}$ (220 mesh) with Al 8011 exhibit superior mechanical properties than the coarse $\mathrm{SiC}-89 \mu \mathrm{m}(150$ mesh) and intermediate $\mathrm{SiC}-76 \mu \mathrm{m}$ (180 mesh) particles.

\section{REFERENCES}

${ }^{1}$ S. Sahin, N. Yüksel, H. Durmus, S. G. Irizalp, Wear behavior of $\mathrm{Al} / \mathrm{SiC} / \mathrm{Graphite}$ and $\mathrm{Al} / \mathrm{FeB} / \mathrm{Graphite}$ hybrid composites, Mater. Tehnol., 48 (2014), 639-646

${ }^{2}$ V. M. Kevorkijan, Experimental investigation of the stability of particulate dispersoid suspensions in aluminum and magnesium melts, Mater. Tehnol., 34 (2000), 419-423

${ }^{3}$ P. Shanmughasundaram, R. Subramanian, G. Prabhu, Some studies on Aluminium - fly ash composites fabricated by two step stir casting method, European Journal of Scientific Research, 63 (2011), 204-218

${ }^{4}$ S. G. Kulkarni, J. V. Meghnani, A. Lal, Effect of fly ash hybrid reinforcement on mechanical property and density of Aluminium 356 alloy, Procedia Material Science, 5 (2014), 746-754, doi:10.1016/ j.mspro.2014.07.324

${ }^{5}$ Sudarshan, M. K. Surappa, Synthesis of fly ash particle reinforced A356 Al composites and their characterization, Materials Science and Engineering A, 480 (2008), 117-124, doi:10.1016/j.msea. 2007.06.068

${ }^{6}$ P. Shanmughasundaram, R. Subramanian, G. Prabhu, Synthesis of Al-fly ash composites by modified two step stir casting method, Advanced Materials Research, 488-489, (2012), 775-781, doi:10.4028/ www.scientific.net/AMR.488-489.775

${ }^{7}$ A. Baradeswaran, A. Elaya Perumal, Study on mechanical and wear properties of $\mathrm{Al} 7075 / \mathrm{Al}_{2} \mathrm{O}_{3} /$ graphite hybrid composites, Composites: Part B, 56 (2014), 464-471, doi: 10.1016/j.compositesb.2013. 08.013

${ }^{8}$ B. Vijaya Ramnath, C. Elanchezhian, M. Jaivignesh, S. Rajesh, C. Parswajinan, A. Siddique Ahmed Ghias, Evaluation of mechanical properties of aluminium alloy-alumina-boron carbide metal matrix composites, Materials and Design, 58 (2014), 332-338, doi:10.1016/j.matdes.2014.01.068

${ }^{9}$ G. B. Veeresh Kumar, C. S. P. Rao, N. Selvaraj , M.S. Bhagyashekar, Studies on Al6061-SiC and $\mathrm{A} 17075-\mathrm{Al}_{2} \mathrm{O}_{3}$ metal matrix composites,
Journal of Minerals \& Materials Characterization \& Engineering, 9 (2010), 43-55, doi: 10.4236/jmmce.2010.91004

${ }^{10}$ R. Harichandran, N. Selvakumar, Effect of nano /micro $\mathrm{B}_{4} \mathrm{C}$ particles on the mechanical properties of aluminium metal matrix composites fabricated by ultrasonic cavitation-assisted solidification process, Archives of Civil and Mechanical Engineering (2015), doi:10.1016/ j.acme.2015.07.001

${ }^{11}$ T. Thirumalai, R. Subramanian, S. Kumaran, S. Dharmalingam, S.S. Ramakrishnan, Production and characterization of hybrid aluminum matrix composites reinforced with boron carbide and graphite, Journal of Scientific \& Industrial Research, 73 (2014), 667-670

${ }^{12}$ J. Hashim, L. Looney, M. S. J Hashmi, Metal matrix composites: production by the stir casting method, Journal of Material Processing and Technology, 92-93 (1999), 1-7, doi:10.1016/S09240136(99)00118-1

${ }^{13}$ P. Pugalenthi, M. Jayaraman, A. Natarajan, Evaluation of mechanical properties of Aluminium alloy 7075 reinforced with $\mathrm{SiC}$ and $\mathrm{Al}_{2} \mathrm{O}_{3}$ hybrid metal matrix composites, Applied Mechanics and Materials, 766-767 (2015), 246-251, doi:10.4028/www.scientific.net/AMM. 766-767.246

${ }^{14}$ S. M. L. Nai, M. Gupta, Influence of stirring speed on the synthesis of $\mathrm{Al} / \mathrm{SiC}$ based functionally gradient materials, Composite Structures, 57 (2002), 227-233, doi: 10.1016/S0263-8223(02)00089-2

${ }^{15}$ N. Radhika, T. V. Balaji, S. Palaniappan, Studies on mechanical properties and tribological behaviour of $\mathrm{LM} 25 / \mathrm{SiC} / \mathrm{AL}_{2} \mathrm{O}_{3}$ composites, Journal of Engineering Science and Technology, 10 (2015), 134-144

${ }^{16}$ K. Komai, K. Minoshima, H. Ryoson, Tensile and fatigue fracture behavior and water-environment effects in a SiC-whisker/7075-aluminum composite, Compos Sci Technol, 46 (1993), 59-66

${ }^{17}$ T. J. A. Doel, P. Bowen, Tensile properties of particulate-reinforced metal matrix composites, Composites Part A, Appl S, 27 (1996), 655-665

${ }^{18}$ C. Sun, M. Song, Z. Wang, and Y. He, Effect of particle size on the microstructures and mechanical properties of SiC-reinforced pure Aluminum composites, Journal of Materials Engineering and Performance, 20 (2011), 1606-1612, doi: 10.1007/s11665-010-9801-3

${ }^{19}$ H. C. Anilkumar, H. S. Hebbar, K. S. Ravishankar, Mechanical properties of fly ash reinforced Aluminium alloy (A16061) composites, International Journal of Mechanical and Materials Engineering, 6 (2011), 41-45

${ }^{20} \mathrm{M}$. Kok, Production and mechanical properties of $\mathrm{Al}_{2} \mathrm{O}_{3}$ particle-reinforced 2024 aluminium alloy composites, Journal of Materials Processing Technology, 161 (2005), 381-387, doi:10.1016/j.jmatprotec. 2004.07.068

${ }^{21}$ M. Rahimian, N. Parvin, N. Ehsani, Investigation of particle size and amount of alumina on microstructure and mechanical properties of Al matrix composite made by powder metallurgy, Materials Science and Engineering A, 527 (2010), 1031-1038. doi:10.1016/j.msea. 2009.09.034

${ }^{22}$ M. Kök, K. Özdin, Wear resistance of aluminium alloy and its composites reinforced by $\mathrm{Al}_{2} \mathrm{O}_{3}$ particles, Journal of Materials Processing Technology, 183 (2007), 301-309, doi:10.1016/j.jmatprotec.2006. 10.021

${ }^{23}$ S. Mahdavi, F. Akhlaghi, Effect of the SiC particle size on the dry sliding wear behavior of $\mathrm{SiC}$ and $\mathrm{SiC}-\mathrm{Gr}-$ reinforced Al6061 composites, Journal of Materials Science, 46 (2011), 7883-7894, doi:10.1007/s10853-011-5776-1 